\section{Investigation of Chlamydia psittaci in pet birds of Uberlândia, Minas Gerais, Brazil}

\author{
Investigação de Chlamydia psittaci em aves de estimação da \\ cidade de Uberlândia, Minas Gerais, Brasil
}

\author{
Andressa Afonso Borges ${ }^{1}$ (D), Daniel Amaral Gontijo² (D), Ana Carolina de Andrade Mello Cintra de Amorin ${ }^{3}$ (D) \& \\ Karinne Spirandelli Carvalho Naves ${ }^{4 *}$ (1) \\ 'Veterinarian. Autonomous, Uberlândia, MG, Brasil \\ Veterinarian. Autonomous, Moema, MG, Brasil \\ ${ }^{3}$ Veterinarian, Resident in Medicina de Animais Selvagens. Clínica Veterinária Vida Silvestre, Uberlândia, MG, Brasil \\ ${ }^{4}$ Dentist, Professor. Departamento de Microbiologia, Instituto de Ciências Biomédicas, Universidade Federal de Uberlândia - \\ UFU, Campus Umuarama, Uberlândia, MG, Brasil
}

\begin{abstract}
Chlamydiosis is a zoonotic disease of public health importance, and its transmission to humans occurs mainly through contact with pet birds. Birds are the second most popular pets in Brazil. Although studies indicate that the disease is endemic in the country, its occurrence is underestimated. Therefore, the present work aimed to investigate the occurrence of Chlamydia psittaci in 68 cockatiels (Nymphicus hollandicus) in the city of Uberlândia, Minas Gerais, Brazil. Samples were collected from choana, cloaca, and fresh fecal samples were also collected for the detection of the bacteria by polimerase chain reaction (PCR) test. Results of the study indicated that the bacteria were absent in the examined samples. This work concluded that it is important to raise the awareness of owners and breeders on measures to prevent and control this disease, and on the public health issues associated with antibiotics overuse.
\end{abstract}

Keywords: psittacosis, ornithosis, zoonosis, cockatiels.

\section{Resumo}

A clamidiose é uma zoonose de importância na saúde pública e sua transmissão para humanos ocorre, principalmente, por meio do contato com aves de estimação. As aves ocupam o segundo lugar no ranking de animais de estimação no Brasil, onde a ocorrência da clamidiose é subestimada, apesar de estudos indicarem que a doença é endêmica no país. Diante disso, o presente trabalho teve como objetivo investigar a ocorrência de Chlamydia psittaci em 68 aves da espécie calopsita (Nymphicus hollandicus) da cidade de Uberlândia-MG. Foram coletadas amostras de coana, cloaca e amostras fecais frescas para a detecção da bactéria por meio do teste da reação em cadeia da polimerase (PCR). A ocorrência encontrada foi nula. Este trabalho concluiu que a conscientização dos tutores e criadores quanto à adoção de medidas para a prevenção e controle dessa doença é importante, e que a orientação destes quanto aos riscos do uso indiscriminado de antimicrobianos é uma questão de saúde pública.

Palavras-chave: psitacose, ornitose, zoonose, calopsitas.

\section{Introduction}

Chlamydiosis, also known as psittacosis or ornithosis (Moschioni et al., 2001), is one of the main zoonoses transmitted by wild birds, and most human cases originate from contact with infected pet birds (Raso, 2014). The pathogen causing the disease is the bacterium Chlamydia psittaci (Ahmed et al., 2017). Currently, C. psittaci or antibodies against the bacterium have been detected in at least 469 wild or pet bird species belonging to 30 orders (Kaleta \& Taday, 2003).

The term "psittacosis" (from the Latin word psittacus, meaning parrot) dates back to 1895, when Morange described an infectious agent transmitted by parrots that causes flu-like symptoms in humans (Vanrompay et al., 1995). However, the term "ornithosis" describes more accurately the potential that several bird species have to transmit the disease (Moschioni et al., 2001). Currently, it is known that this pathogen is endemic in several poultry industries and can cause severe atypical pneumonia in humans (Burnard \& Polkinghorne, 2016).
How to cite: Borges, A. A., Gontijo, D. A., Amorin, A. C. A. M. C., \& Naves, K. S. C. (2020). Investigation of Chlamydia psittaci in pet birds of Uberlândia, Minas Gerais, Brazil. Brazilian Journal of Veterinay Medicine, 42, e107720. https://doi. org/10.29374/2527-2179.bjvm107720

\section{Financial support: None}

Conflict of interests: No conflict of interests declared concerning the publication of this article.

Received: September 19, 2019

Accepted: March 23, 2020.

The study was carried out at performed in the facilities of cockatiel owners and breeders, where the clinical samples were obtained, and at the São Camilo laboratory in Maringá, PR, Brasil where the tests were performed.

\section{*Correspondence}

Karinne Spirandelli Carvalho Naves

Departamento de Microbiologia, Instituto de Ciências Biomédicas - ICBIM, Universidade Federal de Uberlândia - UFU

Avenida Pará, no 1720, bloco 4C, sala 202.

Campus Umuarama

CEP 38400-902 - Uberlândia (MG), Brasil

E-mail: karinne.naves@ufu.br
Copyright Borges et al. This is an Open Access article distributed under the terms of the Creative Commons Attribution Non-Commercial License which permits unrestricted non-commercial use, distribution, and reproduction in any medium provided the original work is properly cited. 
Chlamydia psittaci is a gram-negative intracellular coccobacillus (Proença et al., 2011) that presents two forms in its biological cycle: elementary bodies (EBs), which possess only infectious potential, and reticular bodies (RBs), which possess only reproductive potential. EBs (0.2-0.3 $\mu \mathrm{m}$ ) are metabolically inactive and ensure extracellular survival of the bacterium and host cell infection, while RBs (0.6-1.5 $\mu \mathrm{m})$ are metabolically active and responsible for intracellular replication and generation of infectious bacteria (Raso, 2014).

Wild animals can function as reservoirs for $C$. psittaci and contact with these animals can be a risk factor to the transmission of this zoonosis. The bacterium has already been reported in birds, amphibians, reptiles and mammals, and birds are considered important reservoirs (Burnard \& Polkinghorne, 2016). Pet Psittaciformes, carrier pigeons, and free-living pigeons are the main reservoirs for psittacosis (Beeckman \& Vanrompay, 2009).

Avian chlamydiosis can be acute, subacute, chronic or unapparent, depending on the species and the immune status of the bird, pathogenicity, exposure level, mode of infection, and concomitant diseases. The unapparent form, frequent in adult birds exposed to strains of low and medium virulence, is characterized by the absence of evident clinical signs, representing a diagnostic challenge, and these birds can eliminate C. psittaci intermittently (Proença et al., 2011).

Humans acquire the disease by inhaling C. psittaci in urine aerosols, dried feces, and eye and respiratory secretions from infected birds. Mouth-to-beak contact, pecking and handling of feathers and tissues of these birds also pose a zoonotic risk (Beeckman \& Vanrompay, 2009). Feeder cleaning and direct contact with fecal material are important risk factors for the transmission of this zoonosis (Burnard \& Polkinghorne, 2016).

In cases of human chlamydiosis, death occurs in up to $25 \%$ of untreated patients and in less than $1 \%$ of correctly treated patients (Proença et al., 2011). Early diagnosis and treatment are fundamental for recovery and good therapeutic response. It is important to consider chlamydiosis as a differential diagnosis in cases of community pneumonia that does not respond to conventional antibiotic therapy, with bird contact as an epidemiological factor (Moschioni et al., 2001).

In this context, zoo staff members, veterinarians, biologists, and bird owners are groups at risk for chlamydiosis (Raso, 2014). Most bird species in which the presence of $C$. psittaci or antibodies against the bacterium were detected belong to the Psittaciformes order (Kaleta \& Taday, 2003), represented by parrots, macaws, pionus, and parakeets (Feitosa, 2014).

Avian chlamydiosis is on the list of notifiable animal diseases of the World Organisation for Animal Health (2019). In several countries, such as the United States, this disease is notifiable (Proença et al., 2011). In Brazil, however, notification is mandatory only in cases of human chlamydiosis (Raso, 2014). Although surveys indicate the disease is endemic in Brazil (Raso, 2014), the prevalence of $C$. psittaci in the country is underestimated (Proença et al., 2011).

According to the IBGE (Instituto Brasileiro de Geografia e Estatística, 2013), the number of pet birds in Brazil reached 37.9 million, ranking second only to dogs. Given the great popularity of birds in Brazil, the importance of chlamydiosis in public health and the underestimation of the epidemiological situation of the disease in the country, it is necessary to know the prevalence of $C$. psittaci in different species of pet birds. Especially considering that these animals may be carriers of the microorganism and potential transmitters of this zoonosis to humans.

In view of this, the present study is a survey of the occurrence of Chlamydia psittaci in birds of the cockatiel species (Nymphicus hollandicus), Psittaciformes order, which are very popular pets. The objective of the study was to determine the occurrence of $C$. psittaci in a group of 68 cockatiels from owners and commercial breeders in Uberlândia, MG, Brazil, through the polymerase chain reaction test (PCR) using choana and cloaca swabs and fecal samples.

\section{Materials and Methods}

For the effective detection of C. psittaci, it is recommended by Raso (2014) for samples to be collected from more than one body site. Accordingly, in this study, choana, cloaca, and fresh fecal samples were collected from 68 cockatiels (Nymphicus hollandicus) for the detection of C. psittaci by PCR. Choana and cloaca samples from each bird were obtained by means of individual swabs for each clinical specimen, and the fecal samples from each bird were collected separately on filter paper. The collection kit (swabs and filter paper) was provided by the São Camilo laboratory, in Maringá, PR, where the tests were performed. 
The sampled birds belonged to owners and commercial breeders from Uberlândia, and they did not present clinical signs, with the exception of four birds that showed respiratory noises during collection of samples. In this study, owners who had ten or more cockatiels for commercial purposes were considered breeders, while the others were considered owners.

Between the period of June 6 to 302018 , the clinical samples were obtained directly from the sites where the cockatiels were raised. Visits were made on different days to each of the owners and breeders who consented to participate in the study. After physical restraint of the birds, choana and cloaca samples were collected individually with sterile swabs (ABSORVE, CRAL). Choana swabs were obtained by rubbing the choanal slit, located on the palate, with a plastic rod swab. Cloaca swabs were obtained by introducing a thin metal rod swab (of a suitable size for each bird's cloaca) and scraping the wall of the organ with circular movements. Fresh stool samples were collected on filter paper soon after spontaneous defecation.

The three biological samples from each bird were stored in individual envelopes, packed in Styrofoam boxes, and sent to Maringá for analysis. The equipment and protocol for processing the samples and performing PCR followed the standardized method of Green \& Sambrook (2012). The samples from each bird were pooled together.

This study was approved by the Animal Ethics Committee of the Federal University of Uberlândia (CEUA/UFU), under protocol number 084/17, and the data obtained was analyzed using absolute and relative frequency. The percentage of occurrence of $C$. psittaci in the birds that participated in the study was calculated using the following formula:

Number of infected birds

Number of sampled birds $\times 100$

\section{Results}

PCR tests did not detect the presence of $C$. psittaci in any of the birds evaluated. According to the laboratory, the results do not exclude the possibility of the presence of the bacteria but indicate that the bacterial load may be below the method's sensitivity threshold of 50 copies/ $\mathrm{mL}$ of sample. Of the 68 birds that participated in the study, 13 (19.1\%) belonged to owners and 55 (80.9\%) to breeders.

The facilities of all breeders farms sampled had physical barriers that prevented free-living birds from entering and infecting the captive birds. The cockatiels of groups $1,3,6$, and 7 , totaling 17 animals had no contact with birds of other species. The cockatiels of groups 2, 4, 5, 8, 9, and 10, totaling 51, live with other bird species in the same environment (Figure 1). Therefore, $75 \%$ of the birds that participated in the survey have contact with other species.

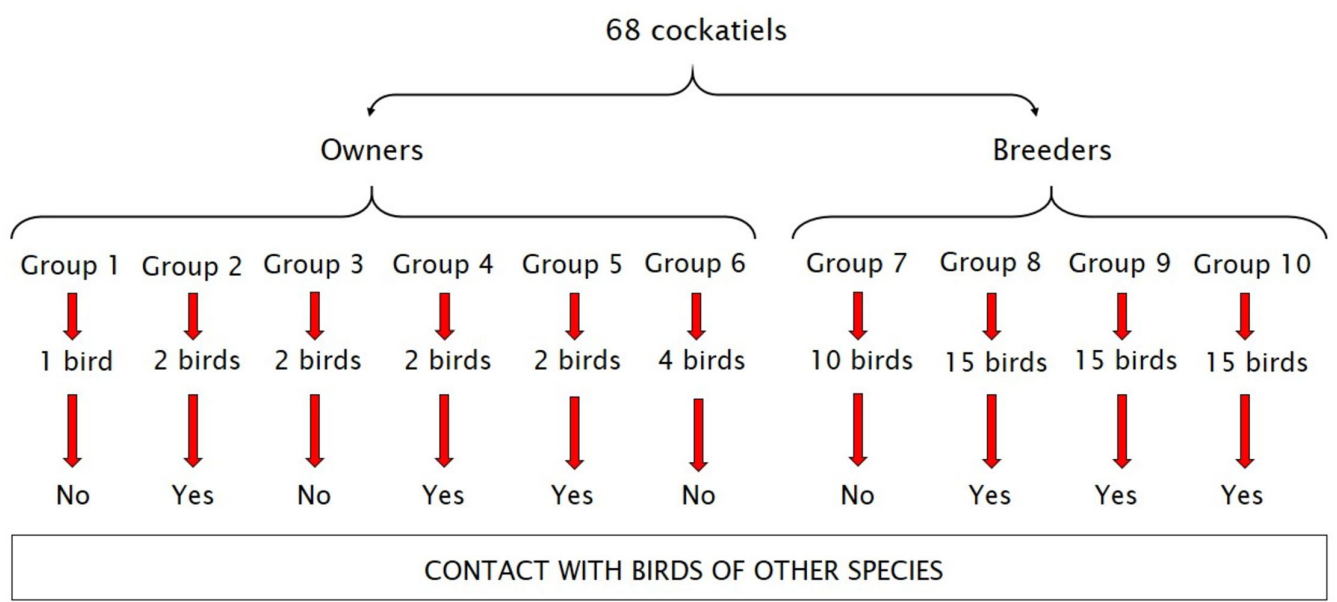

Figure 1. Schematic distribution of the animals used in the study by groups with regards to contact with birds of other species. 


\section{Discussion}

A study by Proença et al. (2010) involving pet birds in the Federal District showed that 38\% (35/92) of the cockatiels evaluated were positive for C. psittaci. All birds that participated in the study had history and clinical signs compatible with chlamydiosis or were positive on routine PCR tests for $C$. psittaci, even without apparent clinical signs. Two stool samples were collected from each bird on alternate days and the material was analyzed by PCR.

Silva (2013) detected C. psittaci in 1.2\% (1/85) of cockatiels from breeders and in none of the 21 birds from owners in the Federal District. Oral swabs were collected from 71 cockatiels and cloacal swabs were collected from all birds (106) evaluated in the study. Biological samples were analyzed by PCR. According to Silva (2013), one of the possible explanations for the low occurrence of $C$. psittaci compared to other studies was the sampling method used. Random sampling avoids bias (Silva, 2013), and biases can occur when sampled birds are selected from a veterinary clinic, where they are taken for treatment at the occurrence of any clinical sign of the disease. Sampling of such birds will likely result in a higher probability of positive results. Proença et al. (2010) used data from animals in a veterinary clinic and selected birds that had history and clinical signs compatible with chlamydiosis or positive result for the disease on routine PCR examinations. Therefore, the chances of detecting positive birds were higher. The present study used a form of sampling similar to Silva (2013), and the birds were obtained from owners and breeders who agreed to contribute to the research, and not from selected cases in veterinary clinics or hospitals.

Different collection methodologies may also have resulted in the differences between results. According to Vasconcelos et al. (2013), the time after exposure to the agent seems to affect the most reliable collection site to detect $C$. psittaci. Since its elimination by feces occurs after primary replication in the upper respiratory tract and bacteremia, oropharyngeal and choana swabs are more consistent in early stages of infection (Raso, 2014), while in more advanced stages, cloacal and fecal samples are more reliable (Vasconcelos et al., 2013). Samples from different sites increases the chances of detecting the microorganism (Raso, 2014).

Considering the intermittent elimination of $C$. psittaci and the different detection sites according to the stage of the disease, Raso (2014) recommends the serial collection of more than one clinical sample in a period of three to five days and/or sample collection from different sites of the animal's body. In this study, samples from three different sites: choana, cloaca and feces were used. Similarly, Silva (2013) collected samples from two sites (cloaca and oral cavity). Proença et al. (2010) collected two fecal samples per bird on alternate days.

In the present study, cockatiels living with other avian species (groups 2, 4, 5, 8, 9 and 10), mainly Agapornis and Australian parakeets (Table 1), which belong to order Psittaciformes, were expected to be positive, because this order had the highest number of species in which C. psittaci bacteria or antibodies had been detected (Kaleta \& Taday, 2003). Proença et al. (2010) reported that $85 \%$ of positive birds had a history of recent contact, i.e., they were acquired or had contact with free-living or captive birds less than a month before. However, the relationship between higher detection and contact was not verified in this study.

Another expected result was that some cockatiels from Group 7 would be positive, considering that during collection four birds presented respiratory noises which exacerbated on physical restraint. However, although C. psittaci is suspected in bird respiratory disorders, the bacterium was not detected. Other tests would be necessary for the differential diagnosis of infectious diseases that affect the respiratory tract of birds, such as aspergillosis and mycoplasmosis (Marietto-Gonçalves, 2016).

Group 9 breeder reported a previous outbreak of chlamydiosis in the cockatiels after acquiring cockatiels from an unknown breeder, and treatment was performed by administering doxycycline in the drinking water. However, as the treatment occurred more than one year before collection of samples, it is expected not to have interfered with the results obtained in this study. To control the disease in the farm, the breeder carried out measures such as disinfection of drinking troughs, feeders, and bottom of cage grids by immersion in bleach or quaternary ammonia every 15 days. In addition, three times a week, the newspaper used to line the cages are changed and quaternary ammonia based disinfectants are sprayed on the cages. 
Table 1. Description of the cockatiel groups regarding type of facility and contact with other avian species.

\begin{tabular}{|c|c|c|}
\hline Group & $\begin{array}{l}\text { No of } \\
\text { cockatiels }\end{array}$ & Type of facility and contact \\
\hline \multirow[t]{2}{*}{1} & 1 & Cage, no contact with chickens living in the backyard \\
\hline & & No contact with other bird species \\
\hline \multirow[t]{2}{*}{2} & 2 & $\begin{array}{l}\text { Cage in the same room with Australian parakeet (Melopsittacus undulatus), } \\
\text { Agapornis (Agapornis sp.), and canary (Serinus canaria) cages }\end{array}$ \\
\hline & & Contact with other species of pet birds, but not free-living birds \\
\hline \multirow[t]{2}{*}{3} & 2 & Birds are free inside the house, there are no other birds \\
\hline & & No contact with other bird species \\
\hline \multirow[t]{2}{*}{4} & 2 & Cage in the same room with Australian parakeet cage \\
\hline & & Contact with another species of pet birds, but not free-living birds \\
\hline \multirow[t]{2}{*}{5} & 2 & $\begin{array}{l}\text { Aviary including Australian parakeets, chickens and chicks, separated by a } \\
\text { screen from Agapornis }\end{array}$ \\
\hline & & Contact with other pet and production bird species, but not free-living birds \\
\hline \multirow[t]{2}{*}{6} & 4 & Part of the day in cage and part in birdhouse, no other birds \\
\hline & & No contact with other bird species \\
\hline \multirow[t]{2}{*}{7} & 10 & Cages, no contact with the ducks living in the backyard \\
\hline & & No contact with other bird species \\
\hline \multirow[t]{2}{*}{8} & 15 & Aviary with Australian parakeets \\
\hline & & Contact with another species of pet birds, but not free-living birds \\
\hline \multirow[t]{2}{*}{9} & 15 & $\begin{array}{l}\text { Cages in the same room with Agapornis, Australian parakeet, canary, zebra } \\
\text { finch (Taeniopygia guttata), Gouldian finch (Erythrura gouldiae) and other } \\
\text { bird cages }\end{array}$ \\
\hline & & Contact with other species of pet birds, but not free-living birds \\
\hline \multirow[t]{2}{*}{10} & 15 & $\begin{array}{l}\text { Cages, separated by a screen from an aviary with Agapornis, blue quails } \\
\text { (Coturnix adansonii) and a domestic pigeon (Columba livia) }\end{array}$ \\
\hline & & Contact with other species of pet birds, but not free-living birds \\
\hline TOTAL & 68 & \\
\hline
\end{tabular}

Group 10 breeder also reported positive birds for C. psittaci, and the treatment was done with doxycycline for 45 days and tylosin for 14 days, and this is repeated annually. Among the measures adopted, the breeder mentioned the placement of a screen to prevent free-living birds from entering the facility in which the cockatiels live, and the bottom of the cages are cleaned every two days and washed with bleach every month.

The use of bleach and quaternary ammonia compounds by groups 9 and 10 breeders corroborates the recommendations by Balsamo et al. (2017). Disinfection with these compounds is effective against $C$. psittaci, which is sensitive to 1:1000 solutions of quaternary ammonia and 1:32 of bleach. Daily cleaning of cages, drinking troughs and feeders is recommended to prevent and control chlamydiosis. The cages should be washed with soap and water and disinfected before being used by different birds. Materials that cannot be properly disinfected, such as wood, should be discarded. In addition, mixing birds from different sources should be avoided, a quarantine period of at least 30 days should be implemented for newly acquired birds, and sick birds should be isolated (Balsamo et al., 2017).

Doxycycline treatment for 45 days is effective, considering negative fecal cultures for C. psittaci (Grespan, 2009). However, the metabolic inactive EBs are not susceptible to antibiotic therapy, so the bird can continue being a carrier even after treatment. Moreover, as the agent has the characteristic of intermittent elimination, the negative cultures do not guarantee the complete 
elimination from the organism of the bird. Therefore, environmental cleaning and disinfection measures are fundamental to control the disease, avoiding reinfection of the sick bird and infection of other birds (Raso, 2014).

However, the annual treatment used by Group 10 breeder is not recommended. According to Ecco et al. (2009), bird owners use tetracyclines for any disease or even prophylactically, it is thus necessary to warn them about the indiscriminate use of these antimicrobials so as to reduce the risk of the emergence of resistant strains, and considering that these same class of antimicrobials are used in the treatment of chlamydiosis in humans.

Extended doxycycline treatments also have a considerably negative impact on the fecal samples of birds collected for bacteria cultures of intestinal microbiota, which results in a decreased capacity to competitively exclude pathogens (Grespan, 2009). Therefore, the indiscriminate use of antimicrobials by breeders is a public health issue not only because it results in increased bacterial resistance, but also because it makes birds more susceptible to other diseases, including zoonotic diseases.

Groups 9 and 10 totaled 30 out of the 68 birds sampled. Therefore, $44.1 \%$ of the birds that participated in the survey came from breeders who implemented chlamydiosis control measures in the flock, which may have influenced the non-detection of $C$. psittaci in this study. The nondetection of the disease in the sampled birds may also have been caused by the fact that no samples were collected during the reproductive, laying or nestling periods, at the instance of the breeders to avoid stressing the animals. According to Harkinezhad et al. (2009), fecal elimination of the bacteria can be activated under stressful conditions related to reproduction and egg-laying.

It was not possible to collect fecal samples from two birds in group 7 and three birds in group 8 , probably owing to physical restraint stress during collection. Initially, the swabs were collected, and subsequently the birds were placed in individual cages or boxes lined with aluminum foil for spontaneous defecation and fecal collection. Some birds took a long time or did not defecate even after more than an hour. To solve this problem, the collection order was reversed, starting with feces and then the swabs.

\section{Conclusions}

Although the studied birds presented no $C$. psittaci, this study shows the need to raise the awareness of owners and breeders about the importance of implementing measures to prevent and control chlamydiosis and to avoid the indiscriminate use of antimicrobial agents.

\section{Acknowledgements}

Owners and breeders who agreed to contribute to the research and Programa Institucional de Bolsas de Iniciação Científica PIBIC/FAPEMIG/UFU.

\section{References}

Ahmed, B., De Boeck, C., Dumont, A., Cox, E., De Reu, K., \& Vanrompay, D. (2017). First Experimental Evidence for the Transmission of Chlamydia psittaci in Poultry through Eggshell Penetration. Transboundary and Emerging Diseases, 64(1), 167-170. http://dx.doi.org/10.1111/tbed.12358. PMid:25882831.

Balsamo, G., Maxted, A. M., Midla, J. W., Murphy, J. M., Wohrle, R., Edling, T. M., Fish, P. H., Flammer, K., Hyde, D., Kutty, P. K., Kobayashi, M., Helm, B., Oiulfstad, B., Ritchie, B. W., Stobierski, M. G., Ehnert, K., \& Tully Jr., T. N. (2017). Compendium of Measures to Control Chlamydia psittaci Infection Among Humans (Psittacosis) and Pet Birds (Avian Chlamydiosis). Journal of Avian Medicine and Surgery, 31(3), 262-282. PMid:28891690.

Beeckman, D. S. A., \& Vanrompay, D. C. G. (2009). Zoonotic Chlamydophila psittaci infections from a clinical perspective. Clinical Microbiology and Infection,15(1), 11-17. http://dx.doi.org/10.1111/j.1469-0691.2008.02669.x. PMid:19220335.

Burnard, D., \& Polkinghorne, A. (2016). Chlamydial infections in wildlife-conservation threats and/or reservoirs of 'spill-over' infections? Veterinary Microbiology, 196, 78-84. http://dx.doi.org/10.1016/j.vetmic.2016.10.018. PMid:27939160.

Ecco, R., Preis, I. S., Martins, N. R. S., Vilela, D. A. R., \& Shivaprasad, H. L. (2009). An outbreak of chlamydiosis in captive psittacines. Brazilian Journal of Veterinary Pathology, 2(2), 85-90. Retrieved in 2019, September 19 , from ttps://bjvp.org.br/wp-content/uploads/2015/07/V.2-N.2-19-20881_2009_12_30_7_20.pdf

Feitosa, F. L. F. (2014). Semiologia veterinária: a arte do diagnóstico (3. ed.). São Paulo: Roca. 
Green, M. R., \& Sambrook, J. (2012). Molecular cloning: a laboratory manual (4th ed.). New York: Cold Spring Harbor Laboratory Press.

Grespan, A. (2009). Clamidiose em calopsitas (Nymphicus hollandicus): perfil do proprietário e ensaio terapêutico (Dissertação de mestrado). Universidade de São Paulo, São Paulo. Retrieved in 2019, September 19, from https://www.teses.usp.br/teses/disponiveis/10/10134/tde-16022011-153259/publico/Andre_Grespan.pdf.

Harkinezhad, T., Geens, T., \& Vanrompay, D. (2009). Chlamydophila psittaci infections in birds: a review with emphasis on zoonotic consequences. Veterinary Microbiology, 135(1-2), 68-77. http://dx.doi.org/10.1016/j. vetmic.2008.09.046. PMid:19054633.

Instituto Brasileiro de Geografia e Estatística - IBGE. (2013). População de animais de estimação no Brasil. Retrieved in 2019, September 7, from http://www.agricultura.gov.br/assuntos/camaras-setoriais-tematicas/ documentos/camaras-tematicas/insumos-agropecuarios/anos-anteriores/ibge-populacao-de-animais-deestimacao-no-brasil-2013-abinpet-79.pdf.

Kaleta, E. F., \& Taday, E. M. A. (2003). Avian host range of Chlamydophila spp. based on isolation, antigen detection and serology. Avian Pathology, 32(5), 435-461. http://dx.doi.org/10.1080/03079450310001593613. PMid:14522700.

Marietto-Gonçalves, G. A. (2016). Manual de emergências aviárias (2. ed.). São Paulo: Editora MedVet.

Moschioni, C., Faria, H. P., Reis, M. A. S., \& Silva, E. U. (2001). Pneumonia grave por "Chlamydia psittaci". Jornal de Pneumologia, 27(4), 219-222. http://dx.doi.org/10.1590/S0102-35862001000400008.

Proença, L. M., Carvalho, C. M., Costa, E. L., Carvalho, A. M., \& Fagliari, J. J. (2010). Estudo epidemiológico e avaliação de diferentes protocolos de tratamento para Chlamydophila psittaci em aves de companhia no Distrito Federal. In: Anais do XIII Congresso ABRAVAS (pp. 5-8). São Paulo: Associação Brasileira de Veterinários de Animais Selvagens. Retrieved in 2019, September 7, from https://www.abravas.org.br/arquivos/2010/2010.pdf

Proença, L. M., Fagliari, J. J., \& Raso, T. F. (2011). Infecção por C. psittaci: uma revisão com ênfase em psitacídeos. Ciência Rural, 41(5), 841-847. http://dx.doi.org/10.1590/s0103-84782011000500017.

Raso, T. F. (2014). Clamidiose - novas abordagens diagnósticas e terapêuticas. In Z. S. Cubas, J. C. R. Silva \& J. L. Catão-Dias (Eds.), Tratado de animais selvagens: medicina veterinária (2. ed., pp. 1369-1379). São Paulo: Roca.

Silva, S. S. (2013). Avaliação clínica, laboratorial e detecção de Chlamydophila psittaci em calopsitas (Nymphicus hollandicus) do Distrito Federal, Brasil (Dissertação de mestrado). Universidade de Brasília, Brasília. Retrieved in 2019, September 7, from http://repositorio.unb.br/bitstream/10482/13618/1/2013_StelaSampaioSilva.pdf

Vanrompay, D., Ducatelle, R., \& Haesebrouck, F. (1995). Chlamydia psittaci infections: a review with emphasis on avian chlamydiosis. Veterinary Microbiology, 45(2-3), 93-119. http://dx.doi.org/10.1016/0378-1135(95)00033-7. PMid:7571380.

Vasconcelos, T. C. B., Nogueira, D. M., Pereira, V. L. A., Nascimento, E. R., \& Bruno, S. F. (2013). Chlamydophila psittaci em aves silvestres e exóticas: uma revisão com ênfase em saúde pública. Enciclopédia Biosfera, 9(16), 2462-2477. Retrieved in 2019, September 7, from http://www.conhecer.org.br/enciclop/2013a/miltidisciplinar/ chlamydophila.pdf

World Organisation for Animal Health - OIE. (2019). OIE-Listed diseases, infections and infestations in force in 2019. Retrieved in 2019, September 7, from http://www.oie.int/animal-health-in-the-world/oie-listed-diseases-2019/ 